\title{
VARIABILITY OF SOIL TYPES IN WETLAND MEADOWS IN THE SOUTH OF THE CHILEAN PATAGONIA
}

\author{
Ladislava Filipová ${ }^{1 *}$, Radim Hédl ${ }^{2}$, and Nilo Covacevich C. $^{3}$
}

\begin{abstract}
The wetland meadows and pastures (vegas) of the agricultural zone of the Magallanes Region and the Chilean Patagonia are productive and intensively exploited ecosystems. However, there is scarce data about the typology and the physical and chemical properties of the soils that determine the agricultural potential of vegas sites. Sampling of the main horizons of 47 soil profiles was conducted throughout the area. The profiles were described in the field and consequently classified according to the soil typology system of the WRB (IUSS Working Group WRB, 2006). Analyses of bulk and particle densities, capillary water capacity, $\mathrm{pH}\left(\mathrm{H}_{2} \mathrm{O}\right), \mathrm{pH}\left(\mathrm{CaCl}_{2}\right)$, texture, organic material, $\mathrm{C}: \mathrm{N}$ ratio, electrical conductivity, effective cation exchange capacity, $\mathrm{N}, \mathrm{P}, \mathrm{Ca}-\mathrm{Mg}-\mathrm{K}-\mathrm{Na}$, exchangeable $\mathrm{Al}$, extractable $\mathrm{Al}$, sulfur $\mathrm{SO}_{4}{ }^{2-}, \mathrm{B}$, and micronutrients $(\mathrm{Cu}-\mathrm{Zn}-\mathrm{Mn}-\mathrm{Fe})$ were carried out. The most frequently recorded groups of soil types in the studied vegas were Histosols - peat soils (20 profiles), and Fluvisols (19). Gleysols (3), Vertisols (1), Regosols (3), Solonchaks (1) and Solonetzs (1) were detected with much less frequency. There is also considerable variability in soil properties among and within the groups of soil types. The principal differences between the Histosols and the Fluvisols are the content of organic matter (often peat), pH level (related to the absence/presence of carbonates) and associated soil properties. Fluvisols are more susceptible to salinization under conditions of aridity, whereas the main threat to Histosols is artificial drainage.
\end{abstract}

Key words: Histosol, Fluvisol, peat, soil properties, salinization, soil degradation.

\section{INTRODUCTION}

In the valleys and canyons of Patagonia, produced by the fusion of Pleistocene glaciers, there are wetland meadows locally called vegas or mallines (Collantes and Faggi, 1999).

According to the Agricultural and Cattle Service (SAG, 2004), the vegas are damp and fertile areas owing to the topography and the characteristics of the soil profile, characterized by a strata of clay at varying depths. High yield grasses with high forage value grow in these areas in spring and summer.

The information about the soils in the vegas of the Chilean Patagonia is scarce. Although Díaz et al. (19591960) analyzed the soils of the entire region, their study

\footnotetext{
${ }^{1}$ University of Jan Evangelista Purkyně (UJEP), Faculty of the Environment, Králova výšina 3132/7, 40096 Ústí nad Labem, Czech Republic.*Corresponding author (ladislava.filipova@ujep.cz).

${ }^{2}$ Institute of Botanic-Academic of Sciences of the Czech Republic, Brno, Czech Republic.

${ }^{3}$ Instituto de Investigaciones Agropecuarias INIA, Casilla 13, Rengo, Chile.

Received: 07 January 2009.

Accepted: 16 April 2009.
}

considered only zonal soils (well developed) and azonal soils (soils that are not well developed because of their youth). The study did not include intra-zonal halomorphic and hydromorphic soils (soils that reflect the dominant influence of local factors or of the topography, over the normal effects of climate and vegetation). Likewise, the soils were classified solely on the basis of their morphological and physical characteristics, because of which the study should be considered as tentative (Sáez, 1994). Another study that encompassed the entire region and a wide variety of habitats, including some types of vegas, was undertaken by Sáez (1994). However, this work did not characterize the entire soil profile, but only the surface layer of $20 \mathrm{~cm}$ of thickness. To the best of our knowledge, there is no modern synopsis of vega soils based on morphological, chemical and physical characteristics yet.

In the steppes, where the water deficiency is aggravated by the high levels of evapotranspiration caused by strong winds, the vegas present communities of high productivity (Covacevich and Ruz, 1996; SAG, 2003) that are used intensively by cattle , and that in some cases present signs of overgrazing (Collantes and Faggi, 
1999). Owing to topographic factors, the vegas suffer very little from natural erosion. Being located in areas with flat or concave relief, they are protected from wind and saturated by water, which allows the development of abundant vegetation (Cruz and Lara, 1987).

SAG published guides on the use of grasslands in Tierra del Fuego and Magallanes in 2003 and 2004, that mention the current conditions of grasslands, their value, applied applications for the farm management, as well as information on overgrazing and erosion (SAG, 2003; 2004). However, changes in soil properties and their relation to vegetation are not discussed. Notable among recent works are the studies of Kleinebecker et al. $(2007 ; 2008)$ about the factors (climatic and biochemical) that affect the botanic composition of the peatlands in the western part of the Region of Magallanes and Chilean Antarctica. These studies focused on the sites least affected by anthropic action in the wettest area of the region and omit the vegas of the steppes that are conditioned by local topographical and pedogenetic factors.

Sheep farming has become the base of the regional economy, representing $50 \%$ of ovine herds in the country (Pérez et al., 1993). Pasture ecosystems, and above all the vegas, are essential for sustaining sheep farming. Because of this, the prudent use of the vegas is indispensible from the point of view of both protection of the natural environment and the economic interests of sheep farmers in the Magallanes.

The present work seeks to present an updated description of the soil types of the vegas of the south of the Chilean Patagonia, indicating their properties and the variability among types, as well as identifying changes in the soil that can contribute to their degradation.

\section{MATERIALS AND METHODS}

\section{Study area}

The study covers the area of agricultural use in the Region of Magallanes and the Chilean Antarctic (Provinces of Última Esperanza, Magallanes and Tierra del Fuego) (48 $36^{\circ}-56^{\circ} 30^{\prime} \mathrm{S}$; $\left.66^{\circ} 25^{\prime}-75^{\circ} 40^{\prime} \mathrm{W}\right)$.

The area is characterized by its cold steppe climate (and the western part for its trans-Andean climate, with steppe degeneration). Annual mean temperatures fluctuate around $7{ }^{\circ} \mathrm{C}$ (Díaz et al., 1959-1960). The thermal regime is characterized by annual thermal amplitude within a relatively low temperature range. The pluviometric gradient in the studied area varies from west to east from $932 \mathrm{~mm}$ annually (1000 $\mathrm{mm}$ according to Schneider et al., 2003) to $233 \mathrm{~mm}$ (Pérez et al., 1993), with lower values in the north of the continental sector, reaching $150 \mathrm{~mm}$ (Collantes and Faggi, 1999).
Colonization of the region began in 1843 with the establishment of Fort Bulnes. The first sheep arrived in 1877 , representing the main base of future wealth in the Magallanes (Martinic, 1986). The most important changes caused by the presence of livestock can be noted in botanic composition, and agricultural activities are reflected in changes in soil properties as well. Nevertheless, this area still presents conditions very close to the natural ones, given that no artificial alterations of hydric regime have occurred. These conditions allow to study pedogenetic e processes and edaphic properties in almost intact environments.

\section{Sampling}

The first part of the study was conducted at the experimental field of the Kampenaike Regional Research Center of the Institute for Agricultural Research (INIA), located $60 \mathrm{~km}$ north of the city of Punta Arenas. Using satellite images, areas with soils saturated by water were chosen, based on the spectral behavior of water in the respective intervals of the electromagnetic spectrum, with the objective was to cover the maximum variability of typologies of vegas (24 profiles). Subsequently, the study was extended to different types of vegas in farms and ranches throughout the region (23 profiles). In total, 47 profiles of different types of vegas were excavated (Table 1). The following characteristics were described in the observed horizons of the profiles (FAO, 2006): color (Munsell color chart), texture, moisture, consistency, structure, presence of stones, roots, edaphon and character of the limits. According to the soil type, the depth of the description varied between 70 and $120 \mathrm{~cm}$ (the minimum of $34 \mathrm{~cm}$ in Kampenaike-Lucho 2, and the maximum of $130 \mathrm{~cm}$ in Kampenaike-Cabeza del Mar 2, Tres Hermanos 2 and Oasy Harbour 2). The soil profile was also photodocumented.

All the profiles were classified according to the guidelines of the international system of the World Reference Base WRB (IUSS Working Group WRB, 2006). The use of the FAO classification is adequate for working purposes, given that it classifies fluvisols and gleysols as homogeneous groups and defines the groups of Calcisols, Gypsisols, Solonchak and Solonetz. The equivalent soil groups of Soil Taxonomy (Soil Survey Staff, 2006) are mentioned.

The soil samples were taken from each horizon of more than (5-) $10 \mathrm{~cm}$ in width. The sample of approximately $1 \mathrm{~kg}$ were taken in plastic bags for analysis and other samples were taken in metal cores $\left(100 \mathrm{~cm}^{3}\right)$, beforehand weighted, for determination of physical characteristics. The samples from bags were air dried and passed through a sieve with $2 \mathrm{~mm}$ diameter holes to separate fine earth that was subsequently analyzed. 
Table 1. Location of the studied profiles.

\begin{tabular}{|c|c|c|c|}
\hline Ranch & UTM location & Kampenaike-farm & UTM location \\
\hline Oazy Harbour 1 & 19F0391324;4164299 & Cerro Caballo 1 & 19F0368505;4157374 \\
\hline Oazy Harbour 2 & 19F0393351;4164302 & Cerro Caballo 2 & 19F0067775;4156768 \\
\hline Quinta Esperanza & 19F0401676;4147744 & Cerro Caballo 3 & 19F0367047;4157897 \\
\hline Shotel Aike & 18F0677397;4311936 & Trinchera & 19F0365593;4156227 \\
\hline Laguna Blanca 1 & 19F0353128;4202000 & Potrero sin nombre-O2 & 19F0368785;4159390 \\
\hline Laguna Blanca 2 & 19F0352595;4204986 & Cabeza del Mar 1 & 19F0071016;4160004 \\
\hline Laguna Blanca 3 & 19F0361852;4225847 & Cabeza del Mar 2 & 19F0371700;4162460 \\
\hline Domaike 1 & 19F0358183;4169455 & Vega Josefina & 19F0362335;4160175 \\
\hline Domaike 2 & 19F0352157;4173300 & Parque/Josefina & 19F0370477;4165476 \\
\hline Domaike 3 & 19F0353014;4170020 & Pesa 2 & 19F0363954;4163124 \\
\hline Los Coipos & 19F0380126;4162433 & Potrero sin nombre-Aa & 19F0368063;4160095 \\
\hline El Álamo & 19F0515511;4066613 & Lucho 2 & 19F0071102;4163024 \\
\hline Miriana & 19F0477485;4132245 & Gali 2 & 19F0366279;4158196 \\
\hline Cerro Castillo & - & Cerro Redondo 1 & 19F0364776;4159884 \\
\hline Vega Vieja & 19F0396507;4205526 & Cerro Redondo 2 & 19F0364537;4160050 \\
\hline Estancia Josefina & 19F0362047;4166475 & Potrero sin nombre-M2 & 19F0369847;4159742 \\
\hline Estancia Springhill & 19F0477297;4165874 & Campo El Monte 1 & 19F0067913;4162976 \\
\hline Tres Hermanos 1 & 19F0481983;4075614 & Campo El Monte 2 & 19F0369144;4161668 \\
\hline Tres Hermanos 2 & 19F0484709;4073821 & Gali 1-1 & 19F0367043;4158832 \\
\hline El Calafate & 19F0363249;4169525 & Gali 1-2 & 19F0366976;4158917 \\
\hline Puerto Consuelo & 18F0664685;4282915 & Sacrificios & 19F0365064;4157370 \\
\hline San Isidro & 19F0520190;4121093 & Los Sauces 1 & 19F0372438;4159941 \\
\hline \multirow[t]{2}{*}{ Las Coles } & 19F0315295;4176077 & Los Sauces 2 & 19F0372025;4159996 \\
\hline & & Consumo & 19F0070527;4159197 \\
\hline
\end{tabular}

UTM: Universal Transverse Mercator.

\section{Analysis of soil samples}

Measurements of $\mathrm{pH}$ in water (soil:water suspension 1:25 ; potentiometry) were made in the laboratory of INIA Kampenaike, as well as evaluations of physical properties: bulk density, particle density, capillarity (the quantity of water that the soil is capable to absorb and retain during suction). The metal cores were dried in an electric oven at $105^{\circ} \mathrm{C}$ for $24 \mathrm{~h}$ and then weighed to estimate bulk density.

The following parameters were subsequently analyzed: texture (Bouyoucos hydrometry method), organic matter (wet combustion method and determination by colorimetry), $\mathrm{C} / \mathrm{N}$ ratio (combustion oven), $\mathrm{pH}$ to $\mathrm{CaCl}_{2}$ (soil:solution suspension 1:2,5; potentiometry), electrical conductivity (suspension 1:5; conductometry), effective cation exchange capacity (ECEC, saturation with sodium acetate, $\mathrm{pH} 7$; by atomic absorption spectrophotometry, AAS), $\mathrm{N}$ mineral $\left(\mathrm{NO}_{3}+\mathrm{NH}_{4}\right)$ (extraction of potassium chloride $2 \mathrm{~N}$, after segmented flow injection), P Olsen

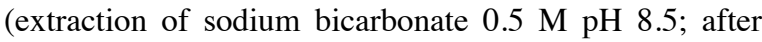
segmented flow injection), Ca-Mg-K-Na (extraction

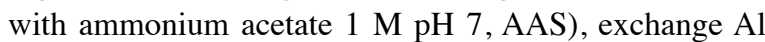
(extraction with chloride of $\mathrm{K} 1 \mathrm{~N}, \mathrm{EAA})$, extractable
$\mathrm{Al}$ (extraction with ammonium acetate $\mathrm{pH} 4.8$; AAS), sulphur $\mathrm{SO}_{4}^{2-}$ (extraction with calcium phosphate 0-01 $\mathrm{M}$; turbidimetry), B (extraction with Ca chloride $0.01 \mathrm{M}$; colorimetry), micronutrients ( $\mathrm{Cu}-\mathrm{Zn}-\mathrm{Mn}-\mathrm{Fe})$ (extraction with diethylenetriamine pentaacetate acid, DPTA, $\mathrm{pH}$ 7; AAS). The analyses were done in the Soil Laboratory of INIA in Chillán.

\section{Statistics}

The descriptive statistics (calculations of averages, standard deviation, minimum and maximum) were proceeded in the program STATISTICA, version 8.0. (StatSoft, 2007). The difference between the histosols and the fluvisols in terms of chemical and physical characteristics were analyzed using the Mann-Whitney U test with the same statistical program. The high organic matter content in the majority of the samples impeded the analysis of texture, because of which the texture was excluded from the analysis.

The remaining soil types were not included in the analysis because they were not well represented in the study (few repetitions that can not be processed correctly 
with statistical methods) and because they did not present properties typical for the majority of the sampled vegas in the area.

\section{RESULTS AND DISCUSSION}

\section{Reference soil groups}

There is a wide variability of vegas related to sedimentological and hydrological conditions that affect pedogenesis. Thus, within a relatively restricted area, such as the experimental station of Kampenaike, there are all types of vegas and its combinations: vegas near rivers/brooks or springs; vegas that surround seasonal or permanent lakes; vegas in concave depressions with impermeable clay horizons (including vegas over lacustrine sediments); and vegas on sediments at the bottom of slopes.

This variability also determines the variability of the reference soil groups. The most common groups in the area are the histosols and the fluvisols.

\section{Histosols (HS)}

Histosols (20 profiles, 43\%) are characterized by the presence of a histic or folic horizon of $40 \mathrm{~cm}$ or more of thickness that begins within $30 \mathrm{~cm}$ from the surface. The folic horizon consists of well-aired organic soil matter. Histic horizons are saturated by water for one or more months in most years, which results in the presence of poorly aired organic matter (IUSS Working Group WRB, 2006). Some $90 \%$ of all Histosols (38\% of all the vegas sampled) have hyperhumic properties (a high organic $\mathrm{C}$ content in the upper meter of soil according to IUSS Working Group WRB, 2006). The stones are not present in any profile within approximately $1 \mathrm{~m}$ from the soil surface. Only five profiles have a stony horizon (4-30\% of the volume) at a depth of more than $1 \mathrm{~m}$. Organic material is formed by vegetal remains, mostly from grasses and sphagnum, and the layer of humolites can reach up to $4 \mathrm{~m}$ and more, while it normally measures around $1 \mathrm{~m}$.

Among the Histosols, we distinguish the following second-level units of the reference soil groups (IUSS Working Group WRB, 2006) according to their morphological (observed in the field), physical and chemical characteristics (specified by laboratory analysis):

Ombri-fibric Histosols - Haplofibrists: This soil is characterized by the fact that two thirds or more of the organic matter (by volume) is formed by recognizable vegetal tissue, and by its moisture level, conditioned by a groundwater. It develops in a proximity of brooks and/or over a masacote (impermeable clay layer formed during the withdrawal of Pleistocene ice, Sáez, 1994). The layers of organic matter in many cases have a thickness of more than $1 \mathrm{~m}$.

- Vegas from: Shotel Aike; Domaike 3; Miriana; Tres Hermanos 1; Tres Hermanos 2; El Calafate; Puerto Consuelo; Vega Josefina; Lucho 2; Cerro Redondo 1; Cerro Redondo 2.

Ombri-folic Histosols - Haplofibrists: Histosols with a folic horizon originating under a regime of moisture conditioned by a layer of water. It is a heterogeneous group of soils that have developed close to rivers with fluviatile contributions (Domaike 1, Kampenaike), on glacial sediments and masacote (Vega Vieja) and on probably lacustrine sediments (Kampenaike) or near a spring (Kampenaike). The layers of organic matter have considerable thickness.

- Vegas from: Domaike 1; Vega Vieja; Los Coipos; Cabeza del Mar 2; Gali 2; Los Sauces 2.

Ombric Histosols - Haplohemists: This is a soil affected by a groundwater in its development, without other characteristics. The soil developed at Josefina Ranch on basic sediments that are probably of lacustrine origin (presence of molluscmollusc shells). The material of origin clearly affected $\mathrm{pH}$, which is only weakly acidic.

Folic Histosols - Haplohemists: The Histosols from Kampenaike Station (Aa), very similar to the previous soil. Nevertheless, drainage has caused the development of a folic horizon. After the loss of water, deep cracks have formed in the organic matter, that limits to a great extent the use of the vega as a pasture.

Episalic Histosols - Sulfihemists: The vega soil rich in organic matter, situated in Kampenaike (Consumo). It has a parasalic horizon (a horizon with secondary enrichment of readily soluble salts found within $1 \mathrm{~m}$ from the soil surface). The thick layer of organic matter is degraded by the deep drainage. Likewise, salt solutions have precipitated in the subsurface horizon forming, together with dry organic matter, an extremely hard layer with a thickness of $27 \mathrm{~cm}$. The cemented salic horizon is almost impenetrable for plant roots. The drainage has also provoked deep cracks in the organic matter (dozens of centimeters) that impede the use as a pasture. A horizon at a depth of 96-100 cm contains light yellow dust, which is probably jarosite $\left(\mathrm{KFe}_{3}\left(\mathrm{SO}_{4}\right)_{2}(\mathrm{OH})_{6}\right)$. The analysis $(\mathrm{pH}-$ $\mathrm{H}_{2} \mathrm{O}<3.5$ and the high $\mathrm{Fe}$ and $\mathrm{S}$ content) supports this theory.

\section{Properties of the Histosols}

The average values of the measured characteristics in the surface-epipedon horizon $(0-20 \mathrm{~cm})$ are shown in Table 2 . 
Table 2. Properties of epipedons of Histosols $(\mathrm{N}=18)$ and Fluvisols $(\mathrm{N}=18)$.

\begin{tabular}{|c|c|c|c|c|c|c|c|c|}
\hline & \multicolumn{4}{|c|}{ Histosols } & \multicolumn{4}{|c|}{ Fluvisols } \\
\hline & Average & Minimum & Maximum & DE & Average & Minimum & Maximum & DE \\
\hline $\mathrm{pH}-\mathrm{H}_{2} \mathrm{O}$ & 6.20 & 5.10 & 7.70 & 0.89 & 7.60 & 5.60 & 10.30 & 1.00 \\
\hline $\mathrm{pH}-\mathrm{CaCl}_{2}$ & 5.90 & 4.70 & 7.50 & 0.95 & 7.30 & 4.80 & 9.60 & 0.98 \\
\hline MO & 60.64 & 21.69 & 84.13 & 15.30 & 31.77 & 1.79 & 75.29 & 22.63 \\
\hline $\mathrm{N}$ & 57.68 & 14.94 & 168.19 & 37.59 & 33.19 & 1.35 & 77.99 & 22.61 \\
\hline $\mathrm{P}$ & 20.46 & 3.36 & 59.22 & 16.32 & 20.15 & 5.90 & 94.31 & 20.36 \\
\hline K & 312.68 & 33.55 & 682.61 & 176.72 & 589.45 & 138.88 & 1909.57 & 417.92 \\
\hline $\mathrm{Ca}$ & 46.04 & 15.45 & 85.85 & 19.92 & 41.04 & 14.06 & 100.92 & 21.22 \\
\hline $\mathrm{Mg}$ & 10.80 & 4.65 & 16.34 & 3.24 & 12.03 & 3.32 & 22.08 & 5.86 \\
\hline $\mathrm{K}_{\mathrm{int}}$ & 0.80 & 0.09 & 1.75 & 0.45 & 1.51 & 0.36 & 4.88 & 1.07 \\
\hline $\mathrm{Na}$ & 5.82 & 1.10 & 13.48 & 3.45 & 12.14 & 1.47 & 31.75 & 8.34 \\
\hline $\mathrm{Al}_{\text {int }}$ & 0.04 & 0.01 & 0.11 & 0.03 & 0.03 & 0.004 & 0.08 & 0.02 \\
\hline ECEC & 63.49 & 30.59 & 114.26 & 24.07 & 66.74 & 34.98 & 137.84 & 27.18 \\
\hline \%sat. Al & 0.09 & 0.01 & 0.35 & 0.11 & 0.06 & 0.01 & 0.23 & 0.06 \\
\hline $\mathrm{Zn}$ & 9.00 & 0.94 & 28.86 & 7.90 & 6.02 & 0.74 & 27.29 & 6.38 \\
\hline $\mathrm{Fe}$ & 1022.64 & 22.53 & 2156.27 & 736.77 & 378.77 & 9.57 & 1900.32 & 478.71 \\
\hline $\mathrm{Cu}$ & 2.35 & 0.02 & 6.69 & 2.24 & 2.29 & 0.31 & 4.07 & 1.20 \\
\hline $\mathrm{Mn}$ & 66.85 & 6.28 & 213.67 & 59.10 & 52.10 & 4.21 & 295.13 & 66.85 \\
\hline B & 3.07 & 0.98 & 6.12 & 1.43 & 3.93 & 0.45 & 14.34 & 3.79 \\
\hline S & 191.85 & 5.47 & 480.33 & 140.42 & 181.11 & 2.48 & 502.26 & 145.49 \\
\hline $\mathrm{Al}_{\mathrm{ext}}$ & 45.28 & 1.00 & 300.0 & 74.59 & 27.72 & 0.00 & 191.00 & 43.87 \\
\hline CE 1:5 & 0.87 & 0.24 & 3.57 & 1.03 & 1.82 & 0.20 & 5.15 & 1.41 \\
\hline $\mathrm{C} / \mathrm{N}$ & 13.95 & 10.71 & 19.88 & 2.68 & 18.44 & 9.91 & 90.44 & 18.40 \\
\hline$\% \mathrm{~N}$ & 2.50 & 1.34 & 3.19 & 0.50 & 1.55 & 0.05 & 3.25 & 1.02 \\
\hline$\% \mathrm{C}$ & 33.93 & 21.04 & 39.60 & 4.63 & 19.77 & 4.31 & 36.09 & 10.34 \\
\hline DR & - & - & - & - & 0.97 & 0.51 & 1.61 & 0.33 \\
\hline DA & 0.24 & 0.12 & 0.42 & 0.08 & 0.49 & 0.18 & 1.30 & 0.31 \\
\hline Сар & 59.67 & 33.20 & 87.00 & 15.81 & 56.80 & 26.30 & 78.50 & 16.96 \\
\hline
\end{tabular}

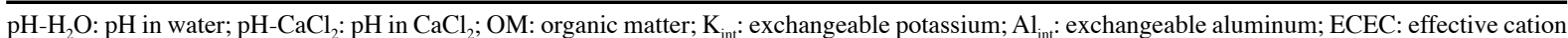
exchange capacity; \%sat. Al: Al saturation capacity; $\mathrm{Al}_{\text {ext }}$ : extractable aluminum; CE 1:5: electrical conductivity; DA: bulk density; DR: particle density; Cap: capillarity; DE: standard deviation; OM: \%; N, P, K: $\mathrm{mg} \mathrm{kg}^{-1} ; \mathrm{Ca}, \mathrm{Mg}, \mathrm{K}_{\text {int }}, \mathrm{Na}, \mathrm{Al}_{\mathrm{c}} \mathrm{cmol}_{(\mathrm{c})} \mathrm{kg}^{-1} ; \mathrm{Zn}, \mathrm{Fe}, \mathrm{Cu}, \mathrm{Mn}, \mathrm{B}, \mathrm{S}, \mathrm{Al}_{\mathrm{ext}}: \mathrm{mg} \mathrm{kg}^{-1} ; \mathrm{CE}_{\mathrm{dS}} \mathrm{d}^{-1}$.

The horizons of Cabeza del Mar 2 and Domaike 1 are not included in the comparisons because the data sets are incomplete.

The $\mathrm{pH}$ values of the surface horizons are in the range of moderately to slightly acidic. Sáez (1994) calculated an average $\mathrm{pH}$ of 5.6 for the organic vegas that correspond to histosols. The different methodologies used can partially explain the differences. However, climatic change resulting in relatively warmer and drier summers (climatic data from Kampenaike) could also affect soil properties.

Other soil properties, such as total $\mathrm{N}, \mathrm{C} / \mathrm{N}$ ratio, $\mathrm{P}, \mathrm{N}$ percentage, $\mathrm{C}$ percentage and soil density are linked to the high organic matter content.

In accordance with Ruz and Covacevich (1989), N deficiency, which appears generalized throughout the region, is the main factor affecting soils in the area. They also emphasized that available water is a limiting factor for plant growth because it is used with low efficiency given the lack of adequate nutrition. However, these authors did not include vegas in their study. The Histosols are rich in $\mathrm{N}$ (with medium and high values), with average $\mathrm{N}$ values twice as high as those reported by Ruz and Covacevich (1989) for prairies.

The ratio of $\mathrm{C} / \mathrm{N}<25$ observed in all of the samples indicates that organic matter is in an easily decomposable state, which implies that the soil is rich in assimilable inorganic N (Duchaufour, 1987).

$\mathrm{P}$ content is low given the scarcity of phosphate minerals (Sáez, 1994). The average values obtained for Histosols are equal to those found in the vegas sampled by Sáez (1994), who points out a close relationship between the content of $\mathrm{Al}$ extractable by $\mathrm{AcNH}_{4} \mathrm{pH} 4.5$ and the $\mathrm{P}$ 
retention capacity (KPo). The higher is the extractable $\mathrm{Al}$ content, the higher is the KPo. The average extractable $\mathrm{Al}$ content in this study was in the low range. However, no correlation was found between $\mathrm{P}$ and extractable $\mathrm{Al}$ in the sampled soils. Only one sample had relatively high $\mathrm{P}$ and extractable $\mathrm{Al}$ values, a vega that was probably occupied by a scrub forest that had been removed (and in part burned) to adapt the soil to pasture. Sáez (1994) also found high $\mathrm{P}$ levels in this type of area. The surface horizons contain high to very high levels of available $\mathrm{K}$, which is particularly due to the accumulation of salts.

According to our data, very high very contents of the exchange cations $\mathrm{Ca}, \mathrm{Mg}, \mathrm{Na}, \mathrm{K}$ are related to conditions of aridity. Sáez (1994) also reported high values of cationic exchange capacity for the epipedon, though not as high as those in this study.

The exchangeable $\mathrm{Al}$ content is very low in the majority of cases, as it is the $\mathrm{Al}$ saturation capacity of the complex of cationic exchange.

The values of the micronutrient contents of $\mathrm{Zn}, \mathrm{Fe}$, $\mathrm{Cu}, \mathrm{Mn}$ and $\mathrm{B}$ varied considerably within the group of Histosols. The averages are generally high and micronutrient deficiency is improbable. Three samples present values of $\mathrm{B}$ higher than $4 \mathrm{mg} \mathrm{kg}^{-1}$, which is toxic for the majority of vegetal species (Sáez, 1994). Likewise, the analyzed samples present a high content of S (sulfate anion, $\mathrm{SO}_{4}^{2-}$ ), which concurs with the results of Sáez (1994).

The average of conductivity values is in the normal range. The majority of the histosols do not have problems of salinity.

Organic soils are characterized by their low bulk density, which is closely related to high organic matter content. On the other hand, maximum capillary capacity, which represents a high capacity of the soil to retain water accessible for plants, is higher owing to the presence of OM.

In some cases mild anthropic erosion can be observed in the form of mounds, caused by compacting and trampling, which generally appear under conditions of heavy animal load (Cruz and Lara, 1987).

The average values of measured characteristics in the $\mathrm{C}$ and $\mathrm{H}$ sub-surface horizons are shown in Table 3.

\section{Fluvisols (FL)}

Fluvisols are soils with fluvic material (refers to fluviatile, marine and lacustrine sediments that receive fresh material at regular intervals or have received it in the recent past). It begins within $25 \mathrm{~cm}$ from the soil surface and continues up to a depth of at least $50 \mathrm{~cm}$ from the soil surface. Fluvic soil is stratified (IUSS Working Group WRB, 2006) and its textures vary from fine sand, clay-sandy or clay.

Fluvisols (40\% of the profiles, in total 19) include different types of soils, given the variability of environmental conditions that occur in perilacunary areas and in river basins.

Haplic Fluvisols - Typic Fluvaquents: This soil presents a typical expression of fluvisol, originating on fluvial sediments of sand in the proximity of a river. In Kampenaike-Cabeza del Mar 1.

Fluvisols (humic) - Fluvaquents: This soil is found on Quinta Esperanza ranch. It presents a high organic C content (more than $1 \%$ of weight of organic $\mathrm{C}$ in the fine earth fraction up to a depth of $50 \mathrm{~cm}$ from the soil surface). This soil originates on fluvial sediments of gravel in a river meander. The A horizon $(10-40 \mathrm{~cm})$ contains around $25 \%$ of the stones (coarse sand and fine gravel) from contributions from the river.

Histic Fluvisols - Fluvaquents: This is heterogenic group of four profiles (Oazy Harbour 1; Domaike 2; Estancia Springhill; M2). Soils with a histic horizon have developed on fluvial sediments (i.e. Domaike 2) or lacustrine sediments (i.e. Oazy Harbour 1, presence of mollusc shells in the sediments).

\section{Thapto-Histic Fluvisols - Thapto-Histic Fluvaquents:} This soil presents a histic horizon buried between 40 and $100 \mathrm{~cm}$ from the surface, and have originated on lacustrine sediments at the edge of a seasonal lagoon in Kampenaike $(\mathrm{O} 2)$. The buried horizon represents a prolonged terrestrial phase in which organic material accumulated. Subsequently, during the aquatic phase, the organic horizon was covered by clay lacustrine sediments of a thickness of $20 \mathrm{~cm}$.

Gleyi-Histic Fluvisols - Fluvaquents: This soil is characterized by a histic horizon and a horizon with gleyic properties, which is within $100 \mathrm{~cm}$ from the surface. It developed under conditions of permanent saturation with groundwater, because of which the C6 horizon shows a pattern of blue-green gleyic colors. The relief of the vega (Cerro Caballo 3) and the presence of mollusc shells in the clay horizon indicate the lacustrine origin of the material.

Endogleyic Fluvisols - Fluvaquents: The Fluvisols in which gleyic properties begin at the depth of $63 \mathrm{~cm}$ from the soil surface. It is found on the shores of a seasonal lagoon in an area with poorly developed vegetation (Campo El Monte 2). The soil is poor in OM and salts precipitate in surface horizons in the form of spherical aggregates. The entire profile presents an extremely high $\mathrm{pH}$ level (between 8.5-9.4). However, it is one of three profiles with living meso- and macro-organisms (earthworms). 
Table 3. Properties of the horizons $\mathrm{C}$ and $\mathrm{H}$ of Histosols $(\mathrm{N}=16)$.

\begin{tabular}{|c|c|c|c|c|c|c|c|c|}
\hline & \multicolumn{4}{|c|}{ Histosols } & \multicolumn{4}{|c|}{ Fluvisols } \\
\hline & Average & Minimum & Maximum & DE & Average & Minimum & Maximum & DE \\
\hline $\mathrm{pH}-\mathrm{H}_{2} \mathrm{O}$ & 6.20 & 5.10 & 7.70 & 0.89 & 7.60 & 5.60 & 10.30 & 1.00 \\
\hline $\mathrm{pH}-\mathrm{CaCl}_{2}$ & 5.90 & 4.70 & 7.50 & 0.95 & 7.30 & 4.80 & 9.60 & 0.98 \\
\hline MO & 60.64 & 21.69 & 84.13 & 15.30 & 31.77 & 1.79 & 75.29 & 22.63 \\
\hline $\mathrm{N}$ & 57.68 & 14.94 & 168.19 & 37.59 & 33.19 & 1.35 & 77.99 & 22.61 \\
\hline $\mathrm{P}$ & 20.46 & 3.36 & 59.22 & 16.32 & 20.15 & 5.90 & 94.31 & 20.36 \\
\hline K & 312.68 & 33.55 & 682.61 & 176.72 & 589.45 & 138.88 & 1909.57 & 417.92 \\
\hline $\mathrm{Ca}$ & 46.04 & 15.45 & 85.85 & 19.92 & 41.04 & 14.06 & 100.92 & 21.22 \\
\hline $\mathrm{Mg}$ & 10.80 & 4.65 & 16.34 & 3.24 & 12.03 & 3.32 & 22.08 & 5.86 \\
\hline $\mathrm{K}_{\mathrm{int}}$ & 0.80 & 0.09 & 1.75 & 0.45 & 1.51 & 0.36 & 4.88 & 1.07 \\
\hline $\mathrm{Na}$ & 5.82 & 1.10 & 13.48 & 3.45 & 12.14 & 1.47 & 31.75 & 8.34 \\
\hline $\mathrm{Al}_{\text {int }}$ & 0.04 & 0.01 & 0.11 & 0.03 & 0.03 & 0.004 & 0.08 & 0.02 \\
\hline ECEC & 63.49 & 30.59 & 114.26 & 24.07 & 66.74 & 34.98 & 137.84 & 27.18 \\
\hline$\%$ sat. Al & 0.09 & 0.01 & 0.35 & 0.11 & 0.06 & 0.01 & 0.23 & 0.06 \\
\hline $\mathrm{Zn}$ & 9.00 & 0.94 & 28.86 & 7.90 & 6.02 & 0.74 & 27.29 & 6.38 \\
\hline $\mathrm{Fe}$ & 1022.64 & 22.53 & 2156.27 & 736.77 & 378.77 & 9.57 & 1900.32 & 478.71 \\
\hline $\mathrm{Cu}$ & 2.35 & 0.02 & 6.69 & 2.24 & 2.29 & 0.31 & 4.07 & 1.20 \\
\hline $\mathrm{Mn}$ & 66.85 & 6.28 & 213.67 & 59.10 & 52.10 & 4.21 & 295.13 & 66.85 \\
\hline B & 3.07 & 0.98 & 6.12 & 1.43 & 3.93 & 0.45 & 14.34 & 3.79 \\
\hline S & 191.85 & 5.47 & 480.33 & 140.42 & 181.11 & 2.48 & 502.26 & 145.49 \\
\hline $\mathrm{Al}_{\mathrm{ext}}$ & 45.28 & 1.00 & 300.0 & 74.59 & 27.72 & 0.00 & 191.00 & 43.87 \\
\hline CE 1:5 & 0.87 & 0.24 & 3.57 & 1.03 & 1.82 & 0.20 & 5.15 & 1.41 \\
\hline $\mathrm{C} / \mathrm{N}$ & 13.95 & 10.71 & 19.88 & 2.68 & 18.44 & 9.91 & 90.44 & 18.40 \\
\hline$\% \mathrm{~N}$ & 2.50 & 1.34 & 3.19 & 0.50 & 1.55 & 0.05 & 3.25 & 1.02 \\
\hline$\% \mathrm{C}$ & 33.93 & 21.04 & 39.60 & 4.63 & 19.77 & 4.31 & 36.09 & 10.34 \\
\hline DR & - & - & - & - & 0.97 & 0.51 & 1.61 & 0.33 \\
\hline DA & 0.24 & 0.12 & 0.42 & 0.08 & 0.49 & 0.18 & 1.30 & 0.31 \\
\hline Cap & 59.67 & 33.20 & 87.00 & 15.81 & 56.80 & 26.30 & 78.50 & 16.96 \\
\hline
\end{tabular}

$\mathrm{pH}-\mathrm{H}_{2} \mathrm{O}$ : $\mathrm{pH}$ in water; $\mathrm{pH}-\mathrm{CaCl}_{2}: \mathrm{pH}$ in $\mathrm{CaCl}_{2} ; \mathrm{OM}$ : organic matter; $\mathrm{K}_{\text {int }}$ exchangeable potassium; $\mathrm{Al}_{\text {int }}$ exchangeable aluminum; ECEC: effective cation exchange capacity; \%sat. Al: Al saturation capacity; $\mathrm{Al}_{\text {ext }}$ : extractable aluminum; CE 1:5: electrical conductivity; DA: bulk density; DR: particle density; Cap: capillarity; DE: standard deviation; OM: \%; N, P, K: $\mathrm{mg} \mathrm{kg}^{-1} ; \mathrm{Ca}, \mathrm{Mg}, \mathrm{K}_{\text {int }}, \mathrm{Na}, \mathrm{Al}_{\mathrm{c}} \mathrm{cmol}_{(\mathrm{c})} \mathrm{kg}^{-1} ; \mathrm{Zn}, \mathrm{Fe}, \mathrm{Cu}, \mathrm{Mn}, \mathrm{B}, \mathrm{S}, \mathrm{Al}_{\mathrm{ext}}: \mathrm{mg} \mathrm{kg}^{-1} ; \mathrm{CE}_{\mathrm{dS}} \mathrm{d}^{-1}$.

Gleyi-episalic Fluvisols - Halaquepts: This is a soil that developed in Kampenaike (Cerro Caballo 2) on lacustrine sediments. It has a shallow sub-surface horizon with gleyic properties and a salic horizon (with a secondary enrichment of readily soluble salts). The salts precipitate in the form of spherical aggregates that are soft and pulverulent when dry.

Fluvisols (calcaric) - Endoaquepts: This soil presents a shallow subsurface horizon with accumulation of secondary calcium carbonate $\left(\mathrm{CaCO}_{3}\right)$. Among the sampled vegas these are the soils that originated over lacustrine sediments. The high $\mathrm{Ca}$ carbonate content, dispersed in the matrix, is, in many cases, due to the presence of mollusc shells that inhabited lakes in the past. Calcaric Fluvisols are concentrated in Kampenaike, in the sectors relatively close to the Straits of Magallanes (vegas Trinchera; Cerro Caballo 1; Gali 1-1). The last profile is from Tierra del Fuego, from San Isidro ranch.

Calcaric-gleyic Fluvisols - Endoaquepts: This soil presents gleyic properties, together with the presence of a calcic horizon. It originates on the shores of a seasonal lagoon in Kampenaike (Sacrificios). The scarcity of vegetal cover and the abundance of halo-tolerant plants indicate prolonged flooding by surface water and strong salinization (the $\mathrm{pH}$ level is extremely high throughout the profile).

Calcaric-episalic Fluvisols - Halaquepts: This is a Fluvisols with high $\mathrm{Ca}$ carbonate content and accumulations of salts that originated over lacustrine sediments in Kampenaike (Los Sauces 1). Salts 
accumulated in the form of coarse aggregates and hard nodules.

Calcaric-humic Fluvisols - Humaquepts: Two profiles (Parque/Josefina; Pesa 2) presented a humic and a calcaric horizons. The soils probably developed over lacustrine sediments.

Hyposalic Fluvisols - Halaquepts: This soil is characterized by high electrical conductivity of the saturated extract. It originated over lacustrine sediments in Kampenaike (Gali 1-2) that contain elevated Ca carbonate contents (molluscs) and above all, salts precipitated in the form of veins.

\section{Properties of Fluvisols}

The average values of the characteristic measured in the surface horizon (epipedon) and in the $\mathrm{C}$ and $\mathrm{H}$ subsurface horizons are shown in Tables 2 and 4, respectively. In general, Fluvisols form a very heterogeneous soil group.

The $\mathrm{pH}$ values are in the range of moderately acidic to strongly alkaline, while the majority of the samples exhibit a neutral $\mathrm{pH}$ to alkaline. Only three samples have a pH less than 7.

There is considerable variability in $\mathrm{OM}$ content and in related properties (total $\mathrm{N}, \mathrm{N}$ percentage, $\mathrm{C}$ percentage, $\mathrm{C} / \mathrm{N}$ ratio, density), which is due to the presence of a histic or humic horizon (rich in $\mathrm{OM}$ ) in a major part of the profiles.

The average $\mathrm{P}$ content is medium. The contents of exchangeable bases are from high to very high in almost all the samples owing to salt accumulations in surface horizons, which also raises conductivity values. More

Table 4. Properties of the Fluvisols horizons $C(N=56)$ and $H(N=10)$.

\begin{tabular}{|c|c|c|c|c|c|c|c|c|}
\hline & \multicolumn{4}{|c|}{ Horizon C } & \multicolumn{4}{|c|}{ Horizon $\mathbf{H}$} \\
\hline & Average & Minimum & Maximum & DE & Average & Minimum & Maximum & DE \\
\hline $\mathrm{pH}-\mathrm{H}_{2} \mathrm{O}$ & 8.40 & 5.70 & 10.30 & 0.77 & 6.90 & 5.60 & 7.60 & 0.73 \\
\hline $\mathrm{pH}-\mathrm{CaCl}_{2}$ & 7.90 & 5.60 & 9.60 & 0.76 & 6.70 & 4.80 & 7.50 & 0.88 \\
\hline $\mathrm{MO}$ & 3.77 & 0.01 & 64.28 & 8.68 & 53.18 & 32.39 & 75.29 & 11.90 \\
\hline $\mathrm{N}$ & 6.67 & 1.00 & 39.06 & 7.59 & 52.28 & 7.44 & 93.48 & 24.96 \\
\hline $\mathrm{P}$ & 4.66 & 1.00 & 70.16 & 10.99 & 21.00 & 2.85 & 94.31 & 26.89 \\
\hline K & 335.32 & 15.45 & 1909.57 & 321.53 & 352.31 & 138.88 & 753.57 & 210.15 \\
\hline $\mathrm{Ca}$ & 27.73 & 3.63 & 125.55 & 24.24 & 48.72 & 24.46 & 65.93 & 14.95 \\
\hline $\mathrm{Mg}$ & 5.58 & 0.88 & 26.62 & 4.65 & 12.91 & 6.16 & 23.08 & 5.16 \\
\hline $\mathrm{K}_{\mathrm{int}}$ & 0.86 & 0.04 & 4.88 & 0.82 & 0.90 & 0.36 & 1.93 & 0.54 \\
\hline $\mathrm{Na}$ & 6.92 & 0.42 & 40.93 & 9.53 & 10.55 & 1.37 & 26.56 & 7.92 \\
\hline $\mathrm{Al}_{\text {int }}$ & 0.02 & 0.004 & 0.07 & 0.02 & 0.03 & 0.01 & 0.08 & 0.02 \\
\hline ECEC & 41.12 & 9.30 & 143.32 & 31.78 & 73.12 & 34.98 & 107.74 & 23.97 \\
\hline$\%$ sat. Al & 0.09 & 0.01 & 0.79 & 0.13 & 0.06 & 0.01 & 0.23 & 0.07 \\
\hline $\mathrm{Zn}$ & 0.78 & 0.09 & 7.75 & 1.10 & 8.39 & 0.49 & 27.29 & 8.35 \\
\hline $\mathrm{Fe}$ & 49.00 & 1.02 & 1030.21 & 146.07 & 625.00 & 40.38 & 1900.32 & 537.08 \\
\hline $\mathrm{Cu}$ & 1.33 & 0.03 & 5.68 & 1.05 & 2.64 & 1.03 & 4.06 & 1.00 \\
\hline $\mathrm{Mn}$ & 11.54 & 0.74 & 94.26 & 15.49 & 67.19 & 0.68 & 295.13 & 85.87 \\
\hline B & 1.40 & 0.09 & 6.07 & 1.44 & 2.76 & 1.44 & 6.03 & 1.49 \\
\hline S & 104.67 & 4.59 & 700.71 & 99.44 & 257.31 & 20.83 & 517.79 & 188.19 \\
\hline $\mathrm{Al}_{\text {ext }}$ & 39.00 & 1.00 & 191.00 & 32.65 & 21.50 & 4.00 & 72.00 & 20.68 \\
\hline CE 1:5 & 1.60 & 0.05 & 10.41 & 2.39 & 1.71 & 0.24 & 4.45 & 1.40 \\
\hline $\mathrm{C} / \mathrm{N}$ & 133.26 & 0.00 & 813.14 & 168.81 & 11.75 & 10.54 & 13.33 & 0.99 \\
\hline$\% \mathrm{~N}$ & 0.14 & 0.00 & 2.87 & 0.39 & 2.33 & 0.98 & 3.25 & 0.71 \\
\hline$\% \mathrm{C}$ & 6.46 & 0.09 & 37.12 & 5.73 & 27.13 & 11.21 & 36.09 & 7.88 \\
\hline DR & 1.37 & 0.73 & 2.01 & 0.33 & 0.86 & 0.51 & 1.25 & 0.22 \\
\hline DA & 0.92 & 0.31 & 1.69 & 0.32 & 0.33 & 0.18 & 0.83 & 0.20 \\
\hline Cap & 47.86 & 15.50 & 78.60 & 14.15 & 62.85 & 26.30 & 82.80 & 20.98 \\
\hline
\end{tabular}

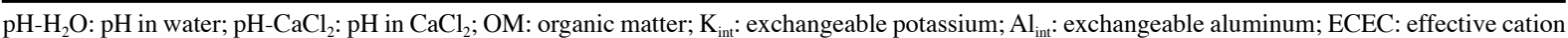
exchange capacity; \%sat. Al: Al saturation capacity; $\mathrm{Al}_{\mathrm{ext}}$ : extractable aluminum; $\mathrm{CE}$ 1:5: electrical conductivity; DA: bulk density; DR: particle density;

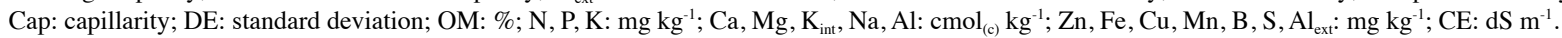


than half the samples exceeded normal values. There are no problems of $\mathrm{Al}$ toxicity given that $\mathrm{Al}$ contents are very low in all the soils.

Likewise, micronutrient contents ( $\mathrm{Zn}, \mathrm{Fe}, \mathrm{Cu}, \mathrm{Mn}, \mathrm{B})$, in the majority of cases, are in the range of high to very high. Four samples have more than $4 \mathrm{mg} \mathrm{kg}^{-1}$ of $\mathrm{B}$, which can negatively affect plant growth.

The fluvisols also have a high capacity of water retention.

\section{Gleysols (GL)}

Gleysols formed 6\% of the profiles analyzed (three profiles in total) and are a minority group of the sampled vegas. The soil materials develop gleyic properties if they are completely saturated by groundwater for a period that allows the occurrence of reduction conditions. They have a gleyic color pattern (reddish-brown or yellowish near the face of the aggregates in the upper part of the profile, together with grayish blue coloring in the interior of the aggregate or more deeply in the soil) (IUSS Working Group WRB, 2006).

Histic Gleysols - Humaquepts: This soil developed close to a river (Oazy Harbour ranch). Conditions of water saturation provoke the accumulation of organic material in the histic horizon, that continues to the depth of 23 $\mathrm{m}$ from the surface. The horizon with gleyic properties, with a thickness of more than $60 \mathrm{~cm}$, has a fluvial origin (alluvial sands) and it is continuously saturated by water.

Para-Histic Gleysols - Humaquepts: The soil developed in a depression with an impermeable substrate created by a glacier, (Kampenaike Ranch, Campo El Monte). Horizon A shows certain features of a histic horizon. A horizon with a gleyic color pattern begins at the depth of $36 \mathrm{~cm}$.

Haplic Gleysols - Fluvaquents: This soil has formed in a concave of a gradual slope near a river meander (El Álamo ranch, Tierra del Fuego). Gleyization is evident in the B horizon, which presents hard aggregates of iron. The soil developed over fluvial sediments of gravel and sand.

The soil types that are not typical of the vegas account for $11 \%$ of all the profiles analyzed (in total five profiles). Compared to the three aforementioned types, they are relatively rare and present specific characteristics given their high salt content or their texture. They are the following types:

\section{Solonchaks (SC)}

These soils have a salic horizon starting within $50 \mathrm{~cm}$ from the soil surface.
Gypsic Solonchaks - Aquisalids: The profile (which is found in a sector near Laguna Blanca) is characterized by its subsurface gypsic horizon occuring at shallow depth. According to the WRB (IUSS Working Group WRB, 2006) this type of horizon is characterized by the fact that is not cemented and contains accumulations of gypsum $\left(\mathrm{CaSO}_{4} 2 \mathrm{H}_{2} \mathrm{O}\right)$ in different forms (in this case, in the form of pseudo-mycelia and compact pulverulent accumulations). Salts more soluble than gypsum accumulate in the upper horizon.

\section{Solonetz (SZ)}

Solonetz is characterized by a natric horizon. It is a dense subsurface horizon, with higher clay content than overlying horizons. It has a high exchangeable $\mathrm{Na}$ and/ or Mg content (IUSS Working Group WRB, 2006) as well.

Gleyic Solonetz - Natrargids: The profile considered in our study have originated on fluvial sediments (Laguna Blanca) in a strongly alkaline environment; the $\mathrm{pH}\left(\mathrm{H}_{2} \mathrm{O}\right)$ of the natric horizon is extremely basic (9.2). The salts form white pulverulent accumulations. Other pedogenetic processes are salinization, which affects the surface horizon, and slight gleyization, which appears in the horizon below the natric horizon. As well as Solonchaks, Solonetz have formed under conditions of scarce precipitation and heavy evapotranspiration. These types of climatic and edaphic conditions favor the development of halophyte vegetation.

\section{Vertisols (VR)}

This soil presents a vertic horizon within $100 \mathrm{~cm}$ from its surface. It is a sub-surface horizon that, as a result of shrinking and swelling, haspolished and grooved surfaces ('slick and slide') or aggregated structures in the form of wedges or cubes. Vertic horizons are clayey and have a hard to very hard consistency (IUSS Working Group WRB, 2006).

Haplic Vertisols haplic - Endoaquerts: Among the studied vegas we found a unique haplic vertisol at the foothill of Cerro Castillo in the north of the Magallanes Region. The vertic horizon is typic and has a thickness of $55 \mathrm{~cm}$. The presence of reddish orange spots in the gray matrix is an evidence of periodic gleyization. The soil developed in a clay material that probably slid from the surrounding slopes and buried an older soil (a buried A horizon was observed). A $0.5 \mathrm{~cm}$ layer formed by the remains of burned vegetation was found at a depth of 80 $\mathrm{cm}$, which could indicate forest fires occurring before the arrival of humans to the region. 


\section{Regosols (RG) - Inceptisols}

Regosols are poorly evolved soils without any diagnostic horizons. There are two soil profiles classified as regosols, sampled only for their comparison to the vegas soils. Their presence in the areas covered in most cases by substrates from the quaternary, is very common. The first profile belongs to a soil developed in an area with abundant vegetation on the shore of a seasonal lagoon in the Laguna Blanca Ranch. This is probably because this soil was formed at the bottom of a transitory lagoon that later disappeared. The B1 horizon has certain features of an argic horizon (above all accumulations of clay in the canaliculi), which supports our theory of the origin of this soil. Likewise, the porous structure and pale color (a result of washing of reduced $\mathrm{Fe}$ ) indicates a lacustrine period in the development of the soil (Daniels and Hammer, 1992). The dominant contemporary edaphogenic process is difficult to distinguish. Although the gleyization observed is notable, this soil cannot be classified as a Gleysols. We found a "boleadora" in the surface horizon (at a depth of $20 \mathrm{~cm}$ ), which shows that this horizon was formed in a sub-recent period (some hundreds of years ago).

The second profile is found in Las Coles ranch. Even thought the owner classifies the land as a vega, it is in fact a prairie originated from a cut forest. The soil is very shallow, developed on glacial sediments of gravel, only processes of ilimerization are noted, which causes the formation of an eluvial horizon (under a regime of abundant precipitation).

Comparison of the properties of Histosols and Fluvisols The comparison of the properties of Fluvisols and histosols is presented in Table 5. The difference in OM content is obvious, given that this differentiates the type of soil. Histosols have an average OM content of $60 \%$ in surface horizons, while Fluvisols have an average of around half of that. The average $\mathrm{N}$ contents differ significantly, probable because of differences in OM content.

Average $\mathrm{P}$ contents are almost the same. The values oscillate between low and medium.

The process of salinization is associated with high $\mathrm{K}$ levels (exchangeable and total) and high $\mathrm{Na}$ levels of the Fluvisols that are thus differentiated from Histosols. Nevertheless, the contents of other exchangeable cations $(\mathrm{Ca}, \mathrm{Mg}, \mathrm{Al})$ and of ECEC do not show any difference between Histosols and Fluvisols.

$\mathrm{Al}$ is very low in all of the measured forms in the surface horizon of all the samples and does not represent any danger of toxicity for plants. Al content is also related to $\mathrm{pH}$ (as $\mathrm{pH}$ decreases, $\mathrm{Al}$ content increases, Sáez, 1994) and consequently Histosols present higher contents. Nevertheless, the values of the majority of samples are
Table 5. Comparison of the characteristics of Fluvisols and Histosols (Mann-Whitney U-test, $p<0.05$ ).

\begin{tabular}{|c|c|c|c|}
\hline & Epipedon & Horizon C & Horizon $\mathrm{H}$ \\
\hline $\mathrm{pH}-\mathrm{H}_{2} \mathrm{O}$ & $<0.01$ & $<0.01$ & $<0.01$ \\
\hline $\mathrm{pH}-\mathrm{CaCl}_{2}$ & $<0.01$ & $<0.01$ & $<0.01$ \\
\hline MO & $<0.01$ & 0.01 & 0.35 \\
\hline $\mathrm{N}$ & 0.04 & $<0.01$ & 0.77 \\
\hline $\mathrm{P}$ & 0.95 & 0.85 & 0.01 \\
\hline $\mathrm{K}_{\mathrm{tot}}$ & 0.01 & $<0.01$ & $<0.01$ \\
\hline $\mathrm{Ca}$ & 0.45 & 0.48 & 0.65 \\
\hline $\mathrm{Mg}$ & 0.59 & 0.18 & 0.10 \\
\hline $\mathrm{K}_{\mathrm{int}}$ & 0.01 & $<0.01$ & $<0.01$ \\
\hline $\mathrm{Na}$ & $<0.01$ & $<0.01$ & 0.047 \\
\hline $\mathrm{Al}_{\text {int }}$ & 0.12 & $<0.01$ & 0.28 \\
\hline ECEC & 0.66 & 0.09 & 0.27 \\
\hline \%sat. Al & 0.15 & $<0.01$ & 0.15 \\
\hline $\mathrm{Zn}$ & 0.22 & $<0.01$ & 0.35 \\
\hline $\mathrm{Fe}$ & 0.01 & $<0.01$ & 0.15 \\
\hline $\mathrm{Cu}$ & 0.61 & 0.06 & 0.20 \\
\hline $\mathrm{Mn}$ & 0.24 & $<0.01$ & 0.75 \\
\hline B & 0.95 & 0.20 & 0.18 \\
\hline S & 0.90 & 0.67 & 0.93 \\
\hline $\mathrm{Al}_{\mathrm{ext}}$ & 0.61 & 0.02 & 0.04 \\
\hline CE 1:5 & 0.01 & 0.03 & 0.45 \\
\hline $\mathrm{C} / \mathrm{N}$ & 0.98 & 0.01 & 0.03 \\
\hline$\% \mathrm{~N}$ & 0.01 & 0.04 & 0.75 \\
\hline$\% \mathrm{C}$ & $<0.01$ & 0.86 & 0.07 \\
\hline Densidad & $<0.01$ & $<0.01$ & 0.048 \\
\hline Cap & 0.63 & $<0.01$ & 0.94 \\
\hline
\end{tabular}

pH- $\mathrm{H}_{2} \mathrm{O}: \mathrm{pH}$ in water; $\mathrm{pH}-\mathrm{CaCl}_{2}: \mathrm{pH}$ al $\mathrm{CaCl}_{2}$; OM: organic matter; $\mathrm{K}_{\text {int }}$ : exchangeable potassium; $\mathrm{Al}_{\text {int }}$ : exchangeable aluminum; ECEC: effective cation exchange capacity; \% sat. $\mathrm{Al}$ : $\mathrm{Al}$ saturation capacity; $\mathrm{Al}_{\mathrm{ext}}$ : extractable aluminum; CE 1:5: electrical conductivity; bulk density; Cap: capillarity; OM: \%; N, P, K: $\mathrm{mg} \mathrm{kg}^{-1} ; \mathrm{Ca}, \mathrm{Mg}, \mathrm{K}_{\text {int }}, \mathrm{Na}, \mathrm{Al}: \mathrm{cmol}_{(\mathrm{cc})} \mathrm{kg}^{-1} ; \mathrm{Zn}$, $\mathrm{Fe}, \mathrm{Cu}, \mathrm{Mn}, \mathrm{B}, \mathrm{S}, \mathrm{Al}_{\text {ext }}: \mathrm{mg} \mathrm{kg}^{-1}$; CE: $\mathrm{dS} \mathrm{m}^{-1}$.

within the range of very slight toxicity. Severe toxicity was detected only in the $\mathrm{C}$ horizons of parasalic Histosols (Kampenaike, Consumo).

Organic soils tend to have greater $\mathrm{Fe}$ compound content, which together with that of $\mathrm{Al}$, is capable of absorbing P (Richardson 1965, cited by Johnston et al., 2001).

No differences were observed in the $\mathrm{C} / \mathrm{N}$ ratio. Among the Fluvisols, one of the samples presents a high value (90.4), which indicates stable forms of OM and low availability of organic N. However, if this sample is omitted, the averages of the $\mathrm{C} / \mathrm{N}$ ratios are almost the same (Fluvisols 14.2, Histosols 13.8). Low values indicate of easily decomposable $\mathrm{OM}$, which determines a high $\mathrm{N}$ content in practically all of the 
surface horizons of all of the soils. The OM content decreases with the depth. The decrease is more notable in Fluvisols, which also have OM that is more difficult to decompose (high $\mathrm{C} / \mathrm{N}$ values) in the $\mathrm{C}$ horizons. The $\mathrm{C}$ and $\mathrm{N}$ ratio in the $\mathrm{H}$ horizons is higher in Histosols. However, almost all of the samples are within the range of easily decomposable OM.

The different percentages of $\mathrm{C}$ and $\mathrm{N}$ are related to the differences in OM content. The significant differences in bulk density and particle density are also linked to OM content. Owing to the high OM content, Histosols have significantly lower density and higher water retention capacity.

\section{CONCLUSIONS}

The predominant soils in the vegas are the Histosols and the Fluvisols, and to a certain degree, the Gleysols. The major differences between the Histosols and the Fluvisols is that the Histosols have higher organic matter content (owing to the humolites originating from insufficient mineralization under the conditions created by the high groundwater level) and the $\mathrm{pH}$ level, which is higher in Fluvisols (because in the majority of cases there are lacustrine sediments with a high content of mollusc shells). Within each group there is considerable variability owing to the topography of the terrain, the hydric regime and management, which are characteristics specific to almost every vega. Macroclimatic conditions (above all precipitation) probably affects soil properties as well. The results presented indicate that there is a considerable variability in the properties of the vegas.

The vegas are important resources for storing water at the local level. This is why it is necessary that a great precaution has to be taken when intervening in them. Although drainage can stimulate the mineralization of $\mathrm{N}$ and its accessibility to plants, at the same time organic soil is compacted and deep cracks are produced. The Histosols are among the most sensitive soils, above all to changes in the hydric regime.

\section{ACKNOWLEDGEMENTS}

The authors are grateful to: Alex Muñoz from the Universidad de Magallanes for drying the samples; all the workers and technicians at INIA CRI Kampenaike, above all to Luis Obando; to Consuelo Sáez and to Manuel Pimentel for correction of the text; and to the ranchers who allowed us to conduct research on their lands. This work was funded by INIA CRI Kampenaike, by the Ministry of Education of the Czech Republic and by the Botanic Institute Project $\mathrm{N}^{\circ}$ AV0Z60050516 of the Academy of Sciences of the Czech Republic.

\section{RESUMEN}

Variabilidad de tipos de suelos en las vegas del sur de la Patagonia chilena. Las praderas húmedas (vegas) de la zona de uso agropecuario de la Región de Magallanes y la Antártica Chilena son ecosistemas productivos e intensamente explotados. No obstante, los conocimientos de los factores edáficos que determinan el potencial de las vegas son escasos. En este trabajo se realizó el muestreo de los horizontes principales de 47 perfiles del suelo de distintos tipos de vegas de la zona. Los perfiles se describieron y se clasificaron siguiendo el sistema de WRB (IUSS Working Group WRB, 2006). Se realizaron análisis de densidad aparente, capilaridad, $\mathrm{pH}$ al agua, $\mathrm{pH}$ al $\mathrm{CaCl}_{2}$, textura, materia orgánica, relación $\mathrm{C} / \mathrm{N}$, conductividad eléctrica, capacidad intercambio catiónico efectiva (ECEC), N mineral, P, Ca-Mg-K$\mathrm{Na}, \mathrm{Al}$ intercambio, $\mathrm{Al}$ extractable, azufre $\mathrm{SO}_{4}{ }^{2-}, \mathrm{B}$ y micronutrientes (Cu-Zn-Mn-Fe). Los grupos de suelos de referencia más comunes en las vegas de la zona son los Histosoles o turbas (20 perfiles) y los Fluvisoles (19). Raramente se pueden detectar los Gleysoles (3), los Vertisoles (1), los Regosoles (2), los Solonchaks (1) y los Solonetzs (1). Existe una considerable variabilidad en las propiedades de los suelos de las vegas entre y también dentro de los grupos de referencia. Las mayores diferencias entre los Histosoles y los Fluvisoles estriban en el contenido de materia orgánica y el pH (relacionado con la presencia o ausencia de carbonatos) y en las propiedades del suelo asociadas. Los Fluvisoles tienden a tener problemas de salinización en condiciones de aridez, mientras que el mayor riesgo para los histosoles es el drenaje artificial.

Palabras clave: Histosoles, Fluvisoles, turba, propiedades del suelo, salinización, degradación del suelo.

\section{LITERATURE CITED}

Collantes, M., y A.M. Faggi. 1999. Los humedales del sur de Sudamérica. p. 14-24. In Malvárez, A.I. (ed.) Tópicos sobre humedales subtropicales y templados de Sudamérica. UNESCO, Montevideo, Uruguay.

Covacevich, N.,y E. Ruz. 1996. Praderas en la zona austral: XII Región (Magallanes). p. 639-655. In Ruiz, I. (ed.) Praderas para Chile. Instituto de Investigaciones Agropecuarias (INIA), Santiago, Chile.

Cruz, G., y A. Lara. 1987. Evaluación de la erosión del área de uso agropecuario de la XII Región de Magallanes y de la Antártica Chilena. Instituto de Investigaciones Agropecuarias (INIA), Santiago, Chile.

Daniels, R., and R. Hammer. 1992. Soil geomorphology. John Wiley and Sons, New York, USA. 
Díaz, C., C. Aviles, y R.C. Roberts. 1960. Los grandes grupos de suelos de la Provincia de Magallanes. Estudio preliminar. Agric. Téc. (Chile) 19-20:227308.

Duchaufour, P. 1987. Manual de edafología. Edit. Masson, Barcelona, España.

FAO. 2006. Guidelines for soil description. $4^{\text {th }}$ ed. 97 p. FAO, Rome, Italy.

IUSS Working Group WRB. 2006. World reference base for soil resources 2006. $2^{\text {nd }}$ ed. World Soil Resources Reports $\mathrm{N}^{\circ} 103.145$ p. FAO, Rome, Italy.

Johnston, C., S. Bridgham, and J. Schubauer-Berigan. 2001. Nutrient dynamics in relation to geomorphology of riverine wetlands. Soil Sci. Soc. Am. J. 65:557-577.

Kleinebecker, T., N. Hölzer, and A. Vogel. 2007. Gradients of continentality and moisture in South Patagonian peatland vegetation. Folia Geobot. 42:363-382.

Kleinebecker, T., N. Hölzer, and A. Vogel. 2008. South Patagonian ombotrophic bog vegetation reflects biogeochemical gradients at the landscape level. J. Veg. Sci. 19:151-160.

Martinic, M. 1986. Nogueira, el pionero. Universidad de Magallanes, Punta Arenas, Chile.

Pérez, C., N. Covacevich, y R. Lira. 1993. Sistemas de pastoreo en cuatro regiones ecológicas de la región patagónica de Chile. In Strauch, O., N. Covacevich, y A. Cárdenas (eds.) El manejo sustentable de las praderas naturales de Magallanes. SOCHIPA en Magallanes. 30 años. Serie Actas INIA N ${ }^{\circ} 35$. Instituto de Investigaciones Agropecuarias (INIA), Punta Arenas, Chile.
Ruz, E., y N. Covacevich. 1989. Respuesta de las praderas de Magallanes a la fertilización NPKS y su modificación por factores de suelo y clima. Agric. Téc. (Chile) 50:33-42.

Sáez, C. 1994. Caracterización de la fertilidad de los suelos de la Región de Magallanes. Informe Final. Proyecto Fundación Fondo Investigaciones Agropecuarias Universidad de Magallanes, Punta Arenas, Chile.

SAG. 2003. El pastizal de Magallanes. Guía de uso, condición actual y propuesta de seguimiento para determinación de tendencia. Gobierno Regional de Magallanes y Antártica Chilena, Ministerio de Agricultura, Servicio Agrícola y Ganadero (SAG) y Departamento de Protección de los Recursos Naturales Renovables, Punta Arenas, Chile.

SAG. 2004. El pastizal de Magallanes. Guía de uso, condición actual y propuesta de seguimiento para determinación de tendencia. Gobierno Regional de Magallanes y Antártica Chilena, Ministerio de Agricultura, Servicio Agrícola y Ganadero (SAG) y Departamento de Protección de los Recursos Naturales Renovables, Punta Arenas, Chile.

Schneider, C., M. Glaser, R. Kilian, A. Santana, N. Butorovic, and G. Casassa. 2003. Weather observations across the southern Andes at $53^{\circ} \mathrm{S}$. Phys. Geogr. 24:97-119.

Soil Survey Staff. 2006. Keys to soil taxonomy. $10^{\text {th }}$ ed. USDA-Natural Resources Conservation Service, Washington, D.C., USA.

StatSoft. 2007. STATISTICA, version 8.0. ČR s.r.o., Prague, Czech Republic. 